\title{
WPS3570
}

\section{Taking Stock of Risk Management \\ Techniques for Sovereigns}

\author{
Stijn Claessens
}

\begin{abstract}
This paper reviews the current state of affairs and thinking on external risk management for developing countries. It tries to identify the reasons behind the limited risk management by sovereigns. Perverse incentives arising from a too generous international safety net, limited access to international financial markets by developing countries arising from low creditworthiness, a limited supply of financial risk management tools suited to developing countries, and a poor supply of skills have inhibited risk management. Another constraint has been the limited attention given to the strategic objectives for risk management. Going forward, the paper identifies actions by international financial markets, countries and international financial institutions that can help improve risk management.
\end{abstract}

World Bank Policy Research Working Paper 3570, April 2005

The Policy Research Working Paper Series disseminates the findings of work in progress to encourage the exchange of ideas about development issues. An objective of the series is to get the findings out quickly, even if the presentations are less than fully polished. The papers carry the names of the authors and should be cited accordingly. The findings, interpretations, and conclusions expressed in this paper are entirely those of the authors. They do not necessarily represent the view of the World Bank, its Executive Directors, or the countries they represent. Policy Research Working Papers are available online at http:/lecon.worldbank.org.

University of Amsterdam and World Bank. Contact: phone 1- 202-473-3484, e-mail SClaessens@,worldbank.org. Paper prepared for the Sovereign Debt Project, organized by Initiative for Policy Dialogue, headed by Joseph Stiglitz, and the Department of Economic and Social Affairs of the United Nations, headed by Jose Antonio Ocampo, and presented on October 14-15, 2004, at Columbia University, New York, and presented at the International Policy Workshop on Debt Sustainability, External Shock and Financing Instruments in Low Income Countries organized by InWEnt, the German Ministry of Economic Cooperation and Development, the German Development Institute, and the World Bank on November 22-23, 2004, Berlin, Germany. I would like to thank the two workshop participants for their comments. 


\section{Introduction}

This paper takes stock of the issues involved in sovereign risk management, focusing on developing countries. It identifies the needs for risk management at the country level by briefly reviewing the various shocks developing countries are exposed to. It then reviews the actual use of risk management tools by developing countries and tries to identify the reasons why risk management has been so limited in practice. It identifies the degree of incompleteness of international financial markets, weak incentives in international markets, poor incentives at the country level and a limited role to date of international financial institutions and international agencies as important reasons behind the lack of risk management. The paper sketches a way forward by analyzing possible actions at various levels to improve risk management.

\section{Issues in risk management for sovereigns and countries}

Type of exposures: multiple and large risks: Developing countries often face large exposures to international risks, more so than the typical developed country. Commodity prices and terms of trade more generally are the most obvious sources of risk where on average developing countries are more exposed than most developed countries are (although there are some exceptions, such as Norway, oil). As recent events have shown again dramatically, climatic shocks and natural disasters, such as drought, earthquakes, hurricanes and others, tend to afflict many developing countries as well, more so than most developed countries. Most developing countries, and especially small countries, 
have limited potential to diversify these natural risks internally. Some of these shocks are partly under the influence of governments as they can take preventive actions, such as building irrigation or dikes, using drought-resistant crops, and other actions, including encouraging diversification. But in many cases these solutions are too costly or inefficient or the shocks are outside the country's influence. Another source of risks are those arising from conflicts and wars, also more prevalent among developing countries, but these are perhaps more endogenous to economic performance.

Since most developing countries are in need of additional funds for investment and thus seek external savings and access to global capital markets, various other risks are introduced. Middle-income countries—-i.e., mainly emerging markets—are often exposed to the vagaries of international capital flows and risks arising from there, e.g., financial contagion arising from crises elsewhere, sudden stops in capital flows, etc. The limited ability for many governments to raise funds in local currencies (externally and/or from international investors) forces them to borrow in claims denominated in foreign exchange and exposes them to the risk of currency adjustment, c.q., devaluations, affecting in turn their overall debt burden in local currency terms. ${ }^{1}$ In addition to these shocks, sometimes endogenous to the countries' own policies, there are purely or largely exogenous risks. Relatively large external debts denominated in non-local currencies make for significant impact of major creditor countries' interest rates changes. And borrowing in a variety of currencies implies that cross-currency exchange rate changes (e.g., dollar, yen, euro) can impact debt burdens. The uncertainty of international capital

\footnotetext{
${ }^{1}$ Of course, the risks of currency devaluations is not independent of the currency structure of debt, nor is the ability of government to issue in local currency independent of their exposure to external shocks, among others.
} 
flows extends itself to the provision of official development assistance, which has been found to be substantially more volatile than domestic fiscal revenues. Furthermore, its volatility grows with aid dependency (see further Bulír and Hamann, 2003).

Many of these risks are not fully exogenous, though. Domestic policies and the country's institutional environment can affect, for example, the degree of international risk-taking by local financial institutions and corporations. The willingness of official lenders to provide assistance may also be a function of the country' policies, thus hindering a smooth flow of assistance. There is also a range of contingent risks that can afflict the fiscal authorities of developing countries, such as those arising from banking and financial crises and vulnerabilities in the corporate sector. More so than in developed countries, governments of developing countries have come to absorb these risks. Although again these risks are to a large extent endogenous to the institutional environment in these countries, to some extent the institutional environment itself is a function of the overall risk the country faces.

Risk management tools: limited available. For developed countries and creditworthy financial institutions and corporations, there have been risk management tools available for several decades to deal with many of these risks. The spectrum of risk management tools and their ease of use have further improved over the past two decades with the introduction of many new derivatives. This has not benefited most developing countries though, mainly as access is more limited and as the supply of risk management tools specifically useful for their situations has been less ample. The smoothing of shocks 
through borrowing (and lending) is limited given the tighter external debt limits for these countries, due to their weaker economic and institutional situations. Importantly, the lack of mechanisms to enforce internationally financial claims and the absence of formal bankruptcy rules at the sovereign level, including the lack of a determination of seniority status, limits the ability and willingness of international financial markets to provide the right forms of external financing, including risk management tools.

The access to financing from the international private sector to smooth has been especially constrained at times of large adverse shocks (and possibly too generous at times of favorable shocks, complicating incentives at the country level). The use of (contingent) credit lines from private sector commercial banks and other financial institutions to deal with shocks has proven to be difficult as amounts remain limited and availability not $100 \%$ assured when needed (among others, due to contingencies within the credit line agreements, such as force majeure). ${ }^{2}$ And these mechanisms come with financial costs (sometimes they require collateral and they always have commitment fees and spreads), which can make them not more attractive than self-insurance. Furthermore, using these tools can send adverse signals on the creditworthiness of the country.

There are hedging instruments (such as short-dated futures and options, and collateralized swaps) that do not raise concerns on credit risks and are available in principle to countries of all credit-standings. These instruments, however, have limited hedging potential as their maturities are shorter and require the ability to raise cash-flow on short notice, i.e.,

\footnotetext{
${ }^{2}$ The credit lines for Argentina, for example, stipulated that the banks could walk out of the contract if Argentina defaulted on its international bonds. Furthermore, the commercial banks may count the credit against their other lending as part of their overall credit limits, thereby negating some of the benefits.
} 
are (even more) akin to forms of self-insurance. Furthermore, they provide price insurance, not value insurance, whereas much of the shocks for developing countries, especially on the export side, relate to unexpected quantity changes uncorrelated with price changes. ${ }^{3}$ They are often also not based on price indexes close enough to the underlying exposures of developing countries to provide a good match. ${ }^{4}$ Furthermore, it may not always be appropriate for small developing countries to use financial riskmitigating instruments. Some commodity risk management markets have strong information asymmetries, as they are quite concentrated, like cocoa, where a few traders in the futures market possess more information than other agents and policy makers do. As a consequence, countries may not stand to get a fair value when participating.

The longer-dated derivatives instruments, which can also be more tailored to the specific circumstances of countries, notably swaps and other OTC products, are less available due to creditworthiness constraints. Longer-dated financing tools, such as GDP-indexed bonds and other real-indexes instruments specifically useful for developing countries are limited available, to date at least. Two examples, the Brady bonds of Bulgaria that included a GDP-indexed recapture clause and the conversion bonds to be issued by Argentina, show some of the difficulties with these instruments. The Bulgarian bonds did not become effective as the bonds were bought back by the government before the clause could have become effective and there were also some design issues. For Argentina, the ongoing negotiations have been very difficult.

\footnotetext{
${ }^{3}$ Most of the small developing countries are price takers but face large output variations, especially in cash crops. See Gilbert and Tabova (2004).

${ }^{4}$ There may be differences, for example, in the grade of commodity exported by the country and the international commodity trade on a futures exchange. Gilbert and Tabova (2004) estimate that international commodity price contingent contracts will consequently only provide very limited risk sharing.
} 
Other tools to manage international risks exist. These have several drawbacks, however, mainly as they are mostly self-insurance schemes. Take for example commodity stabilization funds, which have been tried by a variety of countries (see Newbery and Stiglitz, 1981 for the principles of and earlier experiences with commodity stabilization funds; see Claessens and Duncan, 1993, Priovolos and Duncan 1991, and Dehn, Gilbert and Varangis 2005, for more studies and a recent review). Given the process of many commodity prices, with relatively low rates of mean reversion, i.e., many price behave close to a random walk process, the funds have to be very large to be effective. (In the extreme case of prices that are perfectly random walks, and without some adjustment costs, there is no use having a fund at all since price changes are permanent).

Even with some degree of mean-reversion in prices, funds still involve self-insurance and, as they have to be large given the price processes, are thus quite costly for developing countries. Funds are furthermore vulnerable to political pressures, especially when they get large. Nevertheless, under some circumstances, as experiences from Chile, Norway and some other countries show, there can be a value from funds to smooth, if anything the adjustment of the budgeting processes to international price and revenue changes. Some countries, like Nigeria, are now reevaluating the benefits of commodity stabilization funds.

Constraints within developing countries. As noted, many developing countries lack sufficiently high credit standing to access the longer-dated instruments. This lack of 
credibility is not just reflected in a limited ability for governments to borrow in foreign exchange, but also apparent in their problems in issuing debt in local currency and at fixed interest rates. Few developing countries have, for example, been able to establish deep local bond markets. Furthermore, risk management has had a low political payoff due to the many political constraints, e.g., short political horizons, and potential backlash, e.g., how will unnecessary hedging be perceived ex-post. And the limited human and institutional capacity makes effective risk management, given its technical nature, an even more difficult proposition in most developing countries' public sectors.

These constraints are in part due to a number of structural factors, factors that also complicate sovereign risk management. In general, the dividing lines between public and private risks are fuzzier in developing countries, given a larger involvement of the state in economic decision-making, including often through larger state-ownership, but also through other forms of intervention. Some of this larger role is inherent to the process of development and justifiable. Much of the large role of the state, however, reflects political economy factors where "rents" are allocated through public sector actions, including state ownership, poor regulation and weak or biased enforcement. The outcome gets reflected in part in the presence of much moral hazard, with "too large to fail" (or "too large to ignore") banks, non-bank financial institutions and corporations (see Dooley, 2000, for such a moral hazard model and its effects of risk-taking and financial crises). 
This large involvement and extensive safety net makes sovereign risk management complicated as the objectives become less obvious: should one attempt to reduce risks to the government only, or to the whole country, as the government effectively ends up as the insurer of major parts of the economy? Various answers may exist. The government may only apply risk management for its own balance sheet. Or it may in some dimensions also hedge for the private sector (or "subsidize" its hedging), since that reduces the risks of spillover to the government. Or it may attempt to hedge for the whole economy. The optimal combination may depend, among others, on the incompleteness of domestic markets since that will determine how risks are being allocated within the economy. ${ }^{5}$

Furthermore, there can be barriers for private risk management, including sometimes legal and regulatory restrictions on accessing foreign financial markets. Again, a tradeoff may arise in the context of other imperfections. Some limits on private sector access to foreign financial markets can reduce risks in other ways (e.g., banks may be restricted in their net open foreign exchange positions to mitigate moral hazard concerns). At the same time, this reduced ability to hedge may make the economy more vulnerable to external shocks. Finally, human capacity constraints will be considerable impediments in developing countries. Often, however, the incentive framework is the largest impediment to private sector risk management, with a too large safety net being one of the most important institutional reasons not to hedge.

\footnotetext{
${ }^{5}$ Solé (2004) simulates what the optimal policy might be in the presence of local hedging market imperfections and finds that, depending on the severity of the imperfections, the optimum can be selfinsurance through accumulation of large foreign exchange reserves by the public sector, the provision of a subsidized foreign exchange hedging market, or a laissez faire approach.
} 
Constraints coming from international capital markets. An important international financial markets" "impediment" to having countries improve their risk management is that any gains from risk management accrue to all investors and lenders, not just the one providing the hedging tools or incorporating it in its lending operations. There is thus a coordination problem from improved country risk management: as less risk at the borrower level benefits all lenders, no single lender will require it. And even when risks are being considered at the borrower or project level—where often only a single or a few lenders only are involved, and appropriate risk management techniques are put in place — country or sector-wide risks are not necessarily being considered by individual lenders. ${ }^{6}$

This coordination problem has been aggravated over the past few decades by the increasing number of lenders and investors to developing countries. Whereas two decades ago, a limited number of international banks provided the bulk of financing — or at least were the lead syndicating banks — and largely to governments, now many investors provide financing to a wide variety of borrowers, making for a large number of lenders for any given country. In addition, international financial markets' participants face the moral hazard of existing schemes, especially in countries where official lenders and donors are large, which further reduce their incentives to require better risk management from countries.

\footnotetext{
${ }^{6}$ The country risk assessments being done by commercial banks have shifted away from traditional country risks and now consider more the risk of collective debtor risk, such as the collapse of a large part of the banking system or the corporate sector triggering currency adjustment and possible imposition of balanceof-payments restrictions.
} 
Another constraint coming from the international financial markets is that, while there have been many innovations in financial markets over the last few decades with many new risk management products being developed, this has not always been a direct response to the underlying hedging needs. Rather, the process of financial innovations has often been ad-hoc following major events or in response to government actions or regulations. Indexing to real variables, while very useful in theory, has been especially difficult. Few developed countries, for example, have active markets in real (inflationlinked) government bonds, although the economic case has been made long ago and the techniques for pricing etc, of such indexed bonds are well established. Only active involvement of governments had led to the development of these markets in some industrial countries, such as the UK and US. Indexed bonds exist in some developing countries, e.g., Chile, but more as responses to poor prior macroeconomic policy management, than as an attempt to complete markets.

Similar to the general coordination issues in financial markets, for many other financial innovations (e.g., see collective action clauses), it is hard for any particular creditor or country to introduce them. These coordination issues often hinder the development of instruments specifically useful for developing countries. In addition, issues such as moral hazard and poorer quality of data for developing countries (in case of GDP-indexed bonds where governments are both the provider of data on which the repayments are based and the obligor), illiquidity (given the often smaller issue size), and difficulty in pricing (due to shorter time series) hinder market development. Finally, many 
risks — such as volatile capital flows, contagion, and sudden stops — are hard to quantify and financial risk management tools are consequently difficult to price and develop.

\section{State of Affairs and How to Improve Risk Management}

Outcomes. The outcome of these constraints at the country and international financial markets' level is that there is in practice little risk management by sovereigns or by the private sectors in developing countries. While many private agents in developed countries hedge, most sovereigns, even in developed countries, do not make much use of hedging opportunities, even where active and liquid markets exist and where there is no concern for credit risk. There is a lack of risk management for countries and entities within countries (state-owned enterprises, provinces, etc.) that otherwise have good credit standings. Countries like Norway or states like Alaska, Louisiana and Texas in the US are heavily exposed to oil prices, for example, yet they do not issue oil-indexed bonds or do much hedging. ${ }^{7}$ The limited use of risk management is also the case for exchangetraded futures and options, which exist for most major prices. Although the price indexes may not match perfectly, some risk reduction can still be achieved, yet few sovereigns seem to participate (this observation comes with some caveats since publicly available data to not provide the identity of participants in hedging markets and true participation can thus be higher). These "facts" suggests problems other than creditworthiness play an important role in the unwillingness of sovereigns and public agencies to hedge.

\footnotetext{
${ }^{7}$ Louisiana and Texas used to have commodity-hedging programs, and still have it on their books, but currently do not undertake active price hedging. Alaska has a commodity stabilization fund, but that was not functioning well (see Condon, 2002, who also reviews Louisiana and Texas' experiences). Norway has a "commodity stabilization fund" as it invests a substantial portion of its oil revenues in foreign exchange.
} 
In an international context, as mentioned, part of the reasons lies with the fact that the provision of (cheap) international financial assistance have smoothed shocks. This may especially be true for low-income countries, where many donors have special assistance programs for dealing with various types of shocks. And, of course, for both low- and middle-income countries defaults on official and private bank loans and bonds have been a form of "insurance". But both forms have been ex-post smoothing and mostly insufficient and inefficient. Even tools specifically designed to deal with commodity prices or terms of trade variations and other external shocks (e.g., STABEX, now replaced by FLEX, of the European Commission, the IMF's (Compensatory) and Contingency Financing Facility ((C)CFF), Buffer Stock Financing Facility (BSFF), and other adjustment programs, the World Bank's adjustment lending) are based on ex-post financing. These schemes end up being cumbersome — hard to access as countries need to comply with (additional) reforms and often too late as lags for disbursements are long - and are actually used relatively little. Assistance provided in the context of natural disasters (e.g., the World Bank's Emergency Recovery Loans) has also too often been adhoc and not always timely.

While the intention is counter-cyclical, in light of lags in disbursement, actual aid flows from bilateral donors are, beside very volatile, pro-cyclical (e.g., there is a positive correlation between aid and GDP or fiscal revenues; see further Bulir and Hamman, 2003). If one were to strip out IMF packages to countries in severe distress, multilateral lending itself is likely to be pro-cyclical as well. And, apart from being inefficient, the 
relatively cheap and easy official assistance following external shocks has created moral hazard on the part of borrowers and private lenders in reducing incentives for real and financial risk management.

Self-insurance by countries—incomplete and inefficient as it may be —and frequent financial crises—costly as they may be —are often the outcomes. The self-insurance is most notable in the form of (very) large foreign exchange reserves, especially today in East Asian countries, which by themselves are surely inefficient for countries in early stages of their development. Other forms of risksharing, e.g., through defaults, are inefficient and costly as well. This is true for defaults on both private and official debts, although in the case of the low-income countries largely indebted to official lenders, the costs of default are not as obvious as net transfers to these countries remain high in spite of being de-facto in default; the costs may be mostly in the form of protracted negotiations with lenders.

Although not unambiguously so (from analytical models, it is not clear that higher uncertainty always means lower welfare), having to face more uncertainty likely means costs, as the impact of shocks is asymmetric. This come in terms of reduced investment, higher cost of capital, adjustment programs going off track easier, more pro-cyclical public spending, etc., all leading to lower economic growth. The impact may be even more so for the lower income segment of the populations. Agénor (2004) reviews the evidence and shows that the impact of growth on poverty appears to be asymmetric, resulting from episodes of negative growth rates increasing poverty permanently. 
Improved risk management: Given the large exposures, the large costs, and the limited use of risk management, the scope for improvements would seem to be large. How to improve risk management and what to do will depend on three steps: clarifying the objectives of risk management, assessing what is feasible, and identifying what the various actors — countries, markets and international financial institutions — can and want to do.

Objectives. The starting point will have to be a careful analysis of what one can expect risk management to achieve for countries. The starting point for improved sovereign risk management is often the risk management approach commonly used for corporations or financial institutions in developed countries. A comparison makes quickly clear that risk management for corporations or financial institutions (using derivatives, etc.) is quite different from that for countries. First, risk management for corporations and financial institutions is already quite complex. The best way to illustrate this is to review the risk management decision for a corporation. The easy (or naïve) approach would be to assume that corporations should hedge as much as possible, as the costs of hedging are minimal with efficient financial markets. Considering then hedging as part of the overall liability structure of a firm, an all-equity financed firm would then be optimal as it effectively means laying off all risks to the financial markets. But this ignores some complications. Even for corporations operating in efficient financial markets, un-indexed debt, not equity, is often second best in light of moral hazard and information asymmetries problems. More generally, with principal agent relationships, the second-best contract 
does not necessarily mean full risk sharing. The hedging decision rather needs to be seen as part of the corporation's overall choice of financial instruments available to finance a firm, trading off various agency issues.

Another dimension to consider in the optimal contracting is the incentive of the lender(s). Different contracts provide different incentives for the lenders or investors, especially in two dimensions: to monitor c.q., discipline, and to give advice. With a debt contract, lenders will (or at least should) have an incentive to monitor and discipline the borrower. Many lenders can also add value through their advice, especially direct investors in case of project investments and official and multilateral lenders in case of a country.

Incentives for doing so, however, may conflict with the monitoring role under a debt contract as the payoff on a debt contract is not related to outcomes. In the presence of both monitoring and advising roles, the optimal contract may not be a debt contract, but some combination of debt and equity. ${ }^{8}$ This tradeoff between monitoring and advising is the more complicated for official lenders since their final objective is not (just) achieving a high rate of return on their claims, but furthering development. As such, official lenders have more of an "equity” stake in countries' prospects. To date, however, they have not adjusted their financial contracts accordingly.

Even adjusting for the concerns of ability to pay, moral hazard and information asymmetries, the aim for sovereigns and countries' risk management will still not be that

\footnotetext{
${ }^{8}$ There is a similarity here with the venture capital industry. The venture capitalist (VC) typically is involved not just as a financier, but also provides advice on the business plan of the entrepreneur and may "guide" his investments. The financial contract between the entrepreneur and the VC involves combinations of control and cash flow rights and payoffs schedules that balance the consequent tradeoffs.
} 
pursued by corporations in developed countries. This is because the sovereign status of countries raises the issue of willingness to pay. Countries need not pay back obligations if they do not want, even when they can, whereas corporations can be forced to pay up through a bankruptcy filing. There will be voluntary defaults if the (perceived) costs of continuing to pay are higher than the benefits. These defaults have been frequently observed, even in recent years (such as Argentina, Russia).

The willingness to pay (or default) can be modeled in many ways. As a gross simplification, it can be done assuming either intertemporal or intratemporal economic sanctions. The intertemporal sanctions may be the cutoff from all future lending as banks refuse to lend forever on to the country (Eaton and Gersovitz, 1981), and the intratemporal sanctions may be the inability to trade today as trading partners impose sanctions or otherwise shut the country out from international activities (Bulow and Rogoff, 1989a). ${ }^{9}$ The two "autarky" models can have quite different implications. In the intertemporal case, the country will default when the opportunity costs of not being able to borrow ever again are low, presumably when the current terms of trade are good. ${ }^{10}$ In the intratemporal sanction case, the cutoff from trade may be the least costly when the terms of trade are poor, and the country may then default.

The implications of these two models for optimal financial contracts and associated risk management are quite different. To avoid default, and associated possible bargaining and

\footnotetext{
${ }^{9}$ See also Eaton, Gersovitz and Stiglitz, 1986; Eaton and Fernandez, 1995 review the literature.

${ }^{10}$ This will depend in part on whether the country can save in foreign exchange and use these savings to smooth shocks in the future or whether lenders have access to these savings, i.e., can seize them, in case of default. See Bulow and Rogoff (1989b)
} 
other costs, the payment schedule has to be less in good states under the intertemporal sanctions model. This optimal contract would thus involve very little risk sharing. To avoid default under the intratemporal model, however, payments would have to be lower in the bad states (and higher in the good states), thus achieving more risk sharing. In the intertemporal model, the default constraint thus leads to less risk sharing than in the intertemporal model. At the same time, the country would be still better off with some form of risk sharing. The optimal contract balancing the various constraints may be a debt type loan with some forms of limited risk sharing (see Kletzer and Wright, 2000 for a specific example).

The point of these examples is not so much which is the "correct" model for sovereign debts - neither one of the two is, but rather that the optimal form of risksharing for countries can be quite different from that for corporations. Full international risk sharing is likely not optimal. Rather, the desired amount and type of risk management tools will be those that avoid the bargaining and other costs incurred in defaults, yet at the same time take into account the principal agent and information asymmetries problems. More generally, the benefits from increased risk sharing — whether for corporations or for countries — come from avoiding or reducing certain costs. This will importantly include reducing the costs from adjusting the budget to external shocks. Commodity stabilization funds, for example, may derive their greatest value from allowing for easier budgeting, rather than from smoothing foreign exchange shocks. Furthermore, one needs to differentiate ex-ante and ex-post risks and unexpected from expected price variations. For example, there is risk coming from unexpected price changes and from variability in 
expected prices (such as that due to seasonal variation). The latter is clearly less of concern and cannot be hedged, although it can be smoothed using savings and borrowings.

While full risk sharing is thus not likely the preferred solution, the constraints identified —in terms of access, tools available and the countries' own constraints—may still prevent even the more targeted and limited forms of optimal risk management. What are still possible ways forward to improve risk management and what approaches are feasible? Here is it useful to distinguish between steps that can be undertaken respectively by countries, financial markets and international financial institutions.

Countries. Steps to be taken here concern the degree of risk-taking by the parties within the country, the risk management approaches taken by the government and the possible barriers to risk management for the private and public sectors in the country.

First, countries should consider the allocation of risks between the public and private sectors domestically. They may find that the public sector takes on too much risk or, in some cases, too little. The government may be able shed some risks to the private sector or otherwise change the risk allocation, such that it is faced with those risks that it can bear with the most comparative advantage. How to achieve this shedding or altering of risks will vary from country to country. It may imply continued reform in various dimensions, including liberalization, privatization, altering the nature of public social security obligations or assuring a proper institutional environment in the banking system 
that limits moral hazard. Examples in the real sector of how to alter risk allocation include extending the risk sharing that is already often used in natural resource exploration to other sectors with much price or quantity risks.

These reforms can over time encourage more international risk sharing by the private sector itself. Furthermore, the development of local financial markets, such as bond markets, foreign exchange hedging and other derivatives markets, can reduce the extent of foreign borrowings by corporations and financial institutions and associated risks, and invite more foreign investors to share risks. And, of course, the government can encourage real diversification, even though that itself may be impeded by the volatility the country currently faces. These actions will take time, however, and will not always be available on an efficient scale, especially not for the smaller developing countries.

Arguably, there can exist a trap of volatility making institutional changes and investments in developing new financial markets more difficult.

Second, better, more strategic approaches to sovereign debt and risk management can have high payoffs. A more strategic approach is often needed for several reasons (see Claessens and Kreuser, 2004). There are complex links between the various external risks to consider, but often these are not being considered. An obvious example is that crosscurrency exchange risks (say between the dollar and euro) on external debt may be offset by those incurred on a country's foreign exchange reserves. Coordination between the central bank and the ministry of finance can then lead to easy risk reduction gains, without the need for involvement of external financial markets. Another example is that 
the prices of export and imports, and indirectly fiscal revenues, maybe correlated in some way with major interest rates and currencies. Commodity prices expressed in dollars, for example, have been found to have an inverse relationship with the dollar exchange rate. This potentially creates a natural hedge against some external risks for commodity exporters that also borrow in non-dollar currencies, or actually adds to risks, in case of a commodity importer borrowing in non-dollars. And, as noted, the nature of sovereign liability, with implicit option to default and renegotiate, requires a comprehensive assessment of what risks are optimal to insure against. It is possible, for example, that is more effective to try to insulate again relatively modest shocks, but to allow for renegotiations through partial defaults in case of large shocks. Or, alternatively, the costs of default may be so large that extreme events are best to sure against. These issues need to be evaluated before embarking on a risk management program.

There are also many interrelations between private sector and public sector risk management actions. The private sector may (not) be undertaking risk management in response to public sector actions, creating coordination issues. Risks for the government clearly also depend on private sector's actions, such as the risk of financial crisis. Again, many of these risks are endogenous as agents act according to the institutional environment and react to government policies. The extensiveness of the safety net for financial institutions, for example, will affect the degree of their risk-taking. Or the form of exchange rate management can influence private sector risk-taking behavior, as through more short-term foreign exchange borrowings with a fixed or pegged exchange rate. This in turns requires a strategic review of risk management, including issues such 
as macroeconomic management and the quality of banking regulation and supervision, corporate governance, and the like.

In practice, public sector risk management gets further complicated. A number of questions arise. Due to the various public institutions involved (central bank, ministries, state-owned enterprises), coordination issues arise. Should one pursue a decentralized approach, for example, where say state-owned enterprises hedge on their own, with perhaps some price or quantity adjustments to assure an optimal solution, or a more centralized approach, where all hedging is done in one place? Or can a central entity provide hedging services to other entities on an adjusted price basis? How to coordinate in practice the risk management between the many agencies (central bank, ministries, state-owned enterprises) is difficult in any setting, but even more so in the institutionally weak environments found in many developing countries. Issues of control, oversight and accountability also arise, particularly with the more sophisticated risk management techniques. Many a time a risk management program has ended up in large losses, even in relatively sophisticated settings (e.g., Orange county in the US, Codelco in Chile).

Private sector risk management is neither easy; lack of creditworthiness and know-how hinder many private entities. Scale is a problem, particularly for many cash crops produced on a small-scale (coffee, cocoa). Indeed, small-scale farmers are not potential clients for standard market-based insurance schemes. Commodity boards, the obvious developing country counterparty for international hedging instruments, have been largely closed down by structural adjustment policies. While this may have been for other, good 
reasons, it does leave in many cases a vacuum. Export companies can in principle take on the function of intermediaries of risk management products, but the experience to date suggests that they do not naturally do this. In most market economies, it often is the provider of financing that has instigated the use of risk management, not the trade intermediary. Small firms, though, are less likely to relay on external financing. As a consequence, farmers still get to absorb the risk of short-term price volatility, even though instruments are available.

Many of these concerns are not unique to risk management and also apply to debt, fiscal and public expenditure management more generally. The conditions usually associated with good debt and fiscal management include credible policy-making, solid institutions and good and independent statistics. Good risk management will require in addition in many cases strong back and middle offices that provide the basic data and analysis. What constitutes the minimum institutional setup for effective risk management is hard to say, but surely the simpler the risk management, the lower the requirements. Very sophisticated derivatives hedging programs requiring constant market presence are unlikely to be sustainable in all but a few middle-income countries. Simple hedges put on at some standard points in time are likely the best for many countries. Even better may be tools that combine financing with risk management. Yet, the simplest of these tools, say GDP-indexed bonds, are not available easily, pointing to the need for the supply of tools in financial markets to improve. 
Markets. Markets can help improve risk management. First, financial markets can nudge countries to adopt better risk management. Although there are many coordination issues, there is some scope to increase incentives. Collective action clauses, for example, which recently have been more universally adopted in bonds, tie closer together the incentives of bondholders and may facilitate better risk management. There may be opportunities to reduce barriers in creditor countries, e.g., to adapt the regulations for pension funds and other institutional investors so as to allow and encourage investments in price- or currency indexed (real) bonds. There may also be scope in improving accounting rules such that real, rather than nominal risks are being measured. Clearer analysis of the risks facing developing countries, possibly provided by international financial agencies and institutions, may help coordinate market actions as well.

Second, there may be some scope to encourage financial innovations that can facilitate better risk management, and to introduce new, particularly simple instruments. There have been some new financial instruments, such as natural catastrophe and weather related bonds, which are particularly suited to developing countries (see Gurenko, 2004). A few countries and states, including California and Japan, have issued earthquake bonds. Rainfall and temperature indexed instruments have been used on a small scale, but can be further expanded, particularly through diversification across borders. There have been more exotic suggestions, such as the Shiller macro-type hedges (Shiller, 1993, 2003), the Merton country pension swaps (Bodie and Merton, 2002) and other indexedtype instruments, which have not taken off, even in or among developed countries. Proposals have been recently revived, however, among others by the IMF (IMF, 2004, 
Borensztein and Mauro, 2004) and the US Treasury, especially on GDP-indexed bonds (Council of Economic Advisors, 2004), so there may be progress in the near future.

There are advantages and disadvantages to each of these instruments, including concerns on moral hazard, measurement issues, standardization, and liquidity of instruments. Financial innovations furthermore are costly and may take time to reach sufficient scale. The very fact that the nature of financial innovations is haphazard and that creating actual viable markets is difficult makes it hard to predict whether any of these ideas will take off on a scale significant enough to improve risk management for developing countries. It is still difficult, for example, if not impossible to obtain in any developed country a priceindexed mortgage, while the economic case is strong. Yet, and especially for the simplest of these instruments, there is much more that can be done by international financial agencies.

Official lenders and other international financial institutions. International agencies have a large stake in improved risk management by developing countries for a number of reasons. For one, they ought to be concerned about protecting their own claims on countries exposed to external risks. In principle, as other lenders do, they have an incentive to encourage countries to hedge. The fact that they have been lenders with senior status, however, has reduced their incentives to call for better risk management. Second, and related incentive to require better risk management, is that many a times adjustment programs have gone off track because of external shocks. The fact, for example, that many of the HIPC' countries have already breached their debt ceilings, for 
example, quickly after receiving debt relief has been attributed in part to the adverse shocks these countries have suffered. ${ }^{11}$ Since international agencies have a large (reputational) stake in the success of adjustment programs and maintaining overall macro-economic stability, improved risk management is further in their interests. Third, international financial institutions are very important in influencing countries' overall policy environment, both in term of country specific programs as well as in terms of the overall direction of the official and donor community.

For these reasons, international financial institutions have several incentives to improve overall risk management. They also have several opportunities to do so. One, their own lending and risk management tools can be improved. The existing ex-ante, and ex-post contingent lending mechanisms from international financial institutions are in principle attractive (as they are designed for such shocks and have low costs), but have proven difficult (e.g., see the Contingent Credit Line (CCL) of the IMF). The qualification criteria have been hard to design in such a way to make the mechanisms useful to countries most exposed. And, as with private credit lines, the signal of applying to these instruments (to the CCL especially) has often been perceived negatively by markets, and thus by countries. Rather, it may be more efficient if international financial institutions lend directly on more contingent terms. For many shocks, this may be difficult, but for some clearly exogenous exposures this can be done, e.g., using commodity-price indexed loans. Especially, when risks can be easily diversified internally within lending institutions, such as those arise from energy price changes where both importers and

\footnotetext{
${ }^{11}$ This is not the only reason, and too optimistic projections also played a role in countries' failure not to breach debt ceilings.
} 
exporters are major borrowers, instruments can be usefully provided at very low costs.

Furthermore, the risk of adverse selection is small given official lenders' detailed knowledge of these economies.

To date, these proposals have not gone very far for a variety of reasons. One of which may be that it is more efficient to separate the hedge from the lending instruments, as we observe in most financial markets. Another reason arises from a culture in international financial institutions against financial innovations out of fear of taking on new risks themselves, which argues for the status quo and against developing risk-mitigating loan instruments of their own. But these ideas of indexed loans are still worth exploring. This can be done in the context of Official Development Assistance (ODA) for low-income countries channeled through or in other forms supported by international financial institutions, especially the concessional windows of the World Bank, the International Development Association (IDA). For IDA indexed instruments could be very beneficial for borrowers and the costs to lenders would be minimal. The risk premiums to be charged for providing insurance could be very low as these countries' economic prospects bear little correlation with developed countries' economies; see further Hausmann (2004) for a proposal to denominate IDA lending in local currency units indexed to local inflation. The benefits of improved risk sharing could extend to the lenders' own incentives. Indexing the repayment to the country's prospects may enhance the lenders' incentives to monitor the country and provide it the right type of financing, advice and other support. And, when applied to a large class of official creditors, indexing can avoid the costly renegotiations among creditors in case of non-repayment 
due to shocks, as has been the case to date for debt problems of the low-income countries that are being renegotiated almost continuously in the Paris Club.

Second, the international financial institutions can offer risk management tools to countries where the creditworthiness constraint otherwise prevents access to international financial markets, even when they have no lending (relationship). The World Bank already offers countries swaps and other derivatives, including instruments indexed to commodity prices, but so far it has been a rather disappointing effort to intervene in this area. Although offering these tools overcomes the creditworthiness constraint, very few borrowers have used the options of World Bank intermediated risk management on interest and foreign exchange risks, and none on commodity risks. While this may be partly for reasons internal to the World Bank, ${ }^{12}$ becoming a larger intermediary of risk management tools on demand from countries may still not be realistic without some other changes, including those discussed above. Nevertheless, thought is being given in international financial institutions to develop more efficient "insurance"-type contracts, including those that leverage off private sector instruments.

Third, official lenders could reduce the impact of shocks on their own portfolios, thereby reducing the ex-post impact of shocks on their own future lending and other decisions. The argument is that to the extent that exogenous shocks adversely affect the quality of

\footnotetext{
${ }^{12}$ The use of swaps still counts against the credit ceiling the World Bank uses and has to compete within the overall lending against other lending products. It is not obvious whether the lack of demand represent some distortion as to the way in which derivatives are counted again lending programs, the way in which the dialogues are being conducted on the lending programs (i.e., lending programs may come more with advice and thus be more valuable to the country and/or to the provider) or some other constraint not related to country demand.
} 
loans hinder the development contribution of official lenders, hedging can offer benefits. Arguably, for example, the shocks that led to the over-indebtedness of many low-income countries led to perverse behavior of official lenders, which improved risk management could have avoided.

This is not unique to official lenders, of course, and is much observed in private markets. In the 1980s, for example, the large exposures of many commercial banks to developing countries triggered in part by the rise in interest rates and drop in commodity prices hindered their ability to restructure their exposures in the most efficient manner. Specifically, the US commercial banks that had in the late-1980s large exposures to overindebted developing countries relative to their own capital engaged more in rescheduling than in the more efficient, and ex-post clearly necessary, write-offs. Interesting, the International Finance Corporation (IFC, part of the World Bank group) already engages in hedging its equity investments against some exogenous shocks so as to mitigate the impact on its own balance sheet. Some lessons could be derived from this experience.

Fourth, as with private lenders, borrowers from international agencies may need to be required to include hedges or otherwise show that they have adequate risk management in place. To some extent this is already occurring as the general surveillance of the IMF and specific risk assessments, such as those of the financial system under the Financial Sector Assessment Program (FSAP), identify large vulnerabilities and risk management deficiencies. But these assessments are not yet tied to the lending decision of these and other international financial institutions. Again, there are tradeoffs, since the requirement 
of, say, satisfying a low risk assessment by the IMF or any other seal of "proper risk management" before any lending could take place would create some double conditionality. Furthermore, it could hamper the development objectives of the international financial institutions as many developing countries have limited choices (to hedge and to attain proper institutions) and have to accept some degree of risks.

Fifth, international financial institutions could become more active in several ways other than directly related to their own lending and adjustment programs. They could, for example, set standards for new risk management tools. For example, they can define the most useful risk management product for certain type of borrowers, e.g., puts for some type of countries, or swaps for others. They can introduce objective indexes to be used for (new) risk management tools, e.g., an index for certain, not so standard commodity prices. They can help overcome the coordination and liquidity issues in financial markets by the large issuance of indexed instruments especially useful for developing countries. In the first instance, the international financial institutions need not intermediate these instruments, but rather they could just issue indexed instruments and then lay off these risks back in the international capital markets. The World Bank has done some of this, by issuing various linked instruments (gold price, exchange-rate linked), which were then hedged by international banks with the after-hedged costs passed on to the Bank. These were pure arbitrage-based borrowings, however. Instead, there could be more strategic issuance so as to jump-start a market. For example, the World Bank could issue a commodity-linked bond or a general emerging markets' GDP-indexed bond. There may also be scope to introduce markets for securities that are in zero-net supply. For example, 
one can conceive of an index that has good hedging benefits for developing countries but has low correlation with developed countries' financial markets. A market could be made by third-parties in this security, where the official agencies could take various roles, e.g., develop the methodology, set the daily value of the index, provide clearing and settlement services, be a market maker, etc.

\section{Conclusions}

Better sovereign risk management for countries is much needed, but will remain difficult. Current practices can be enhanced though and new tools can be introduced at low costs. The starting point has to be the incentive framework for risk management on both the borrower and lenders' sides. For borrowers, much scope lies in the improvement of countries' institutional infrastructure, such that more risks are delegated away from the public sector toward the private sector. For international markets, while some innovations are possible in terms of altering incentives and adding new products, the larger barrier is the coordination problem inherent in financial markets.

The most promising start in terms of changes in financial contracting might be to redesign the contracts at which official lending takes place for low-income countries. A specifically useful suggestion is to introduce more indexing to the country's economic outcomes, e.g., GDP-indexed loans. The benefits can be three-fold: the country benefits from more risk-sharing, while the costs to the lenders are minimal; there is a greater alignment of the interests as lenders directly share in the prospects of the country; and there is reduced scope for conflicts among creditors in case of defaults, thereby reducing 
the ex-post negotiations costs. Cost aspects involve managing the risk of moral hazard and the difficulty of measuring GDP objectively. Making the instruments as simple as possible and some oversight over national statistics collection and production will be necessary.

In addition, international agencies can help introduce better risk management tools in a number of ways, among others by: providing objective price indexes on risks of interest to developing countries, e.g., commodity prices indexes, rainfall and other climatic indexes, etc.; developing markets in "zero-supply type" securities, such as a "low correlation" security, which third parties could trade in. The international agencies can provide the index, trading systems and/or settlement and clearing systems, and help start the market; issuing indexed liabilities and thereby jump-starting and creating markets in tools of specific interest to developing countries; and intermediating more risk management tools by lending and using derivatives innovatively. 


\section{References}

Agénor, Pierre-Richard, 2004, Macroeconomic Adjustment and the Poor: Analytical Issues and Cross-Country Evidence. Journal of Economic Surveys, Vol. 18, No. 3, pp. 351-408, July.

Bodie, Zvi, and Robert Merton. 2002, International Pension Swaps. Journal of Pension Economics and Finance 1(1), January, pp. 77-83.

Borensztein, Eduardo and Paolo Mauro (2004). The Case for GDP-indexed Bonds. Economic Policy 38, April: 165-216.

Bulíř, Aleš and A. Javier Hamann, 2003, Aid Volatility: An Empirical Assessment, IMF Staff Papers, 50(1): 64-89.

Bulow, Jeremy and Kenneth Rogoff, 1989a. A Constant Recontracting Model of Sovereign Debt, Journal of Political Economy, February, 97(1): 155-78

Bulow, Jeremy and Kenneth Rogoff, 1989b. Sovereign Debt: Is to Forgive to Forget? American Economic Review, 79:1, April, pp. 43-50

Claessens, Stijn and Ronald Duncan (Eds.), 1993 Managing Commodity Price Risk in Developing Countries Using Financial Instruments: Case Studies, John Hopkins University Press, Baltimore.

Council of Economic Advisers. 2004. Growth-Indexed Bonds: A Primer. United States Council of Economic Advisers, White Paper.

Dehn, Jan, Christopher L. Gilbert and Panos Varangis, forthcoming, Commodity Price Volatility, chapter in Joshua Aizenman and B. Pinto eds., Volatility and its Consequences for Crises and Growth: A Handbook For Practitioners. Cambridge University Press 
Dooley, Michael, 2000. A Model of Crises in Emerging Markets, The Economic Journal, 110, No. 460, January, pp. 256-272.

Eaton, Jonathan and Raquel Fernandez, 1995. Sovereign Debt, in Grossman, G. and R. Kenneth (Eds.), Handbook of International Economics, Vol. 3, pp. 2031-77, Amsterdam; New York and Oxford: Elsevier, North-Holland.

Eaton, Jonathan, and Mark Gersovitz, 1981. Debt with Potential Repudiation: Theoretical and Empirical Analysis, The Review of Economic Studies, 48:2, April, pp. 289-309.

Eaton, Jonathan, Mark Gersovitz and Joseph Stiglitz, 1986, Pure Theory of Country Risk, European Economic Review, 30(3), June 1986, pp. 481-513.

Christopher L. Gilbert, and Alexandra Tabova, 2004, Commodity Prices and Debt Sustainability, at www.PerformanceTrading.it

Claessens, Stijn and Jerome Kreuser, 2004. A Framework for Strategic Foreign Reserves Risk Management, in Carlos Bernadel, Pierre Cardon, Joachim Coche, Francis X. Diebold, and Simone Manganelli (Eds.), Risk Management for Central Bank Foreign Reserves, European Central Bank, Frankfurt, 47-73.

Condon, Wilson L. 2002, Hedging Oil Revenues What is it? When should Alaska do it, if at all? Why should Alaska consider it?, Alaska Department of Revenue, October 21, at: http://www.revenue.state.ak.us/treasury/publications/Hedgingfinal.pdf

Gurenko, Eugene, 2004, (Eds.) Catastrophe Risk and Reinsurance: A Country Risk Management Perspective, Risk Books, London, UK. 
Hausmann, Ricardo and Roberto Rigobon, 2004, IDA in UF: On the benefits of changing the currency denomination of concessional lending to low-income countries, mimeo, Harvard University.

International Monetary Fund, 2004, Sovereign Debt Structure for Crisis Prevention, July 2, Discussion Paper, IMF, Washington, D.C.

Kletzer, Kenneth, David M. Newbery and Brian D. Wright, 1992, Smoothing Primary Exporters' Price Risks: Bonds, Futures, Options and Insurance, Oxford Economic Papers, 44(4): 642-671.

Kletzer, Kenneth, and Brian Wright, 2000, Sovereign Debt as Intertemporal Barter, American Economic Review, Vol. 90, June 2000, pp. 621-639.

Newbery, David, and Joseph Stiglitz, 1981, The Theory of Commodity Price Stabilization, Oxford: Oxford University Press.

Priovolos, Theophilos and Ronald Duncan (Eds.), Commodity Risk Management and Finance, Oxford: Oxford University Press, 1991.

Shiller, Robert J., 1993, Macro Markets: Creating Institutions for Managing Society's Largest Economic Risks. Oxford, United Kingdom: Clarendon Press.

— 2003, The New Financial Order: Risk in the 21st Century Oxford, United Kingdom, and Princeton, New Jersey: Princeton University Press.

Solé, Juan, 2004, Should Central Banks Hedge Foreign Exchange Risk? Unpublished; Washington: International Monetary Fund, International Capital Markets Department. 